\title{
Originals
}

\section{C-Peptide Reserve in Insulin-dependent Diabetes}

\section{Comparative Responses to Glucose, Glucagon and Tolbutamide}

\author{
R. D. Mirel ${ }^{1,4}$, Fredda Ginsberg-Fellner ${ }^{2}$, D. L. Horwitz ${ }^{3,5}$, and E. J. Rayfield ${ }^{1}$ \\ Departments of ${ }^{1}$ Medicine and ${ }^{2}$ Pediatrics, Mount Sinai School of Medicine, New York, New York, and ${ }^{3}$ Department of Medicine, \\ University of Chicago School of Medicine, Chicago, Illinois, USA
}

\begin{abstract}
Summary. Residual beta cell secretory capacity was assessed in short term ( 2 months to 2 years) and long term ( 5 to 8 years) insulin-dependent diabetics by measurement of serum C-peptide immunoreactivity during three provocative tests: glucose, tolbutamide, and glucagon. Minimal C-peptide secretion could be detected in only one out of seven long term diabetics by the stimulatory tests. All seven short-term diabetics responded to at least one provocative test of beta cell reserve, although these responses were blunted. The greatest C-peptide responses occurred after glucagon administration (mean increase $0.62 \mathrm{pmol} / \mathrm{ml}$ ) in short-term responders. Patients who responded to one test did not necessarily respond to another stimulus. There was no correlation between basal C-peptide levels and the ability to provoke further C-peptide secretion by any of the three tests. C-peptide responses did not correlate with \% Haemoglobin $\mathrm{A}_{1 \mathrm{c}}$, mean fasting blood glucose levels, or mean blood glucose concentrations during an oral glucose tolerance test. The data indicate that stimulation tests are only useful in assessing endogenous beta cell reserve in patients with diabetes of less than 5 years duration. In diabetics of longer duration there is little insulin reserve above basal levels.
\end{abstract}

Key words: Beta cell reserve, C-peptide, insulindependent diabetes, comparative responses, glucose, glucagon, tolbutamide, Haemoglobin $\mathrm{A}_{1 \mathrm{c}}$.

The importance of C-peptide immunoreactivity $(\mathrm{CPR})$ as an index of endogenous beta cell reserve in

\footnotetext{
${ }^{4}$ Present address: Dedham Medical Associates, Dedham, Massachusetts

${ }_{5}^{5}$ Present address: Department of Medicine, University of Illinois Medical Center, Chicago, Illinois
}

insulin-dependent diabetes, and its clinical implications, have been the subject of several recent reports [1-7]. While refinements of assay techniques for CPR have led to more precise evaluation of insulin reserve under a variety of conditions [8-10], little data is available comparing several provocative stimuli for C-peptide in the same group of patients. The present study was designed to evaluate beta cell reserve measured by CPR in insulin-dependent (type 1) diabetes employing three provocative stimuli: glucose, tolbutamide and glucagon [11-13]. Stimulation tests were performed in two groups of type 1 diabetics: those of recent onset (less than 2 years) and those of longer duration (greater than 5 years). Correlations were sought between the results of the tests and various indices of glycaemic control.

\section{Materials and Methods}

Fourteen insulin-dependent diabetics, ranging in age from 10 to 21 years and with diabetes of 2 months to 8 years duration, were studied. Clinical data of these diabetics are presented in Table 1. Seven had diabetes mellitus of recent onset ( 2 months to 2 years) prior to being studied and seven had diabetes of longer duration ( 5 to 8 years). No patients were receiving other drugs of any kind. Eleven patients were receiving one daily morning injection of insulin while 3 patients were receiving two daily injections, the second being at $1700 \mathrm{~h}$. Informed consent was obtained from the parents and from each patient. Between $0800 \mathrm{~h}$ and $1000 \mathrm{~h}$ on three separate days within a three week period each patient underwent a series of three tests following a ten hour overnight fast. The patients received their usual insulin dose on the day prior to each test but no insulin was administered on the morning of the tests. An indwelling scalp vein needle attached to a three way stop-cock was inserted into an arm vein at least one-half hour prior to each test and kept patent with a slow infusion of $0.15 \mathrm{~mol} / \mathrm{l}$ saline. A $4 \mathrm{~h}$ oral glucose tolerance test (GTT) using $1.75 \mathrm{~g} / \mathrm{kg}$ body weight up to $100 \mathrm{~g}$ glucose was administered. Samples were collected for plasma glucose, glucagon, and serum CPR at $0,30,60,120,180$, and $240 \mathrm{~min}$. On separate days glucagon $(30 \mu \mathrm{g} / \mathrm{kg})$ and tolbutamide $(30 \mathrm{mg} / \mathrm{kg})$ were administered IV with samples for 
Table 1. Clinical and laboratory data

\begin{tabular}{|c|c|c|c|c|c|c|c|c|c|}
\hline $\begin{array}{l}\text { Patient } \\
\text { Number }\end{array}$ & Sex & $\begin{array}{l}\text { Age } \\
\text { years }\end{array}$ & $\begin{array}{l}\text { Duration of } \\
\text { diabetes } \\
\text { (years) }\end{array}$ & $\begin{array}{l}\% \text { ideal } \\
\text { body weight }\end{array}$ & $\begin{array}{l}\text { total daily } \\
\text { insulin dose }\end{array}$ & Mean F G & $\begin{array}{l}\text { Mean } \\
\text { plasma glu- } \\
\text { cose } \\
(\mathrm{mg} / 100 \mathrm{ml}) \\
\text { during GTT }\end{array}$ & $\mathrm{HbA}_{1 \mathrm{c}}$ & $\begin{array}{l}\text { Serum trig- } \\
\text { lyceride } \\
(\mathrm{mg} / \mathrm{dl})\end{array}$ \\
\hline 1 & $\mathbf{M}$ & 19 & 0.17 & 73 & 22 & 233 & 328 & 5.1 & 101 \\
\hline 2 & $\mathrm{~F}$ & 12 & 0.17 & 108 & 8 & 250 & 333 & 8.3 & 59 \\
\hline 3 & M & 13 & 0.50 & 116 & 56 & 313 & 420 & 8.0 & 46 \\
\hline 4 & $\mathbf{M}$ & 13 & 0.67 & 99 & 34 & 309 & 470 & 9.1 & 14 \\
\hline 5 & $\mathbf{M}$ & 11 & 1.08 & 121 & 18 & 313 & 492 & 6.7 & 10 \\
\hline 6 & $\mathrm{~F}$ & 13 & 1.33 & 97 & $60^{(+)}$ & 404 & 509 & 10.2 & 397 \\
\hline $7 \boldsymbol{A}$ & M & 17 & 2.0 & 102 & 4 & 265 & 371 & 5.2 & 65 \\
\hline \multicolumn{10}{|l|}{$\begin{array}{l}\text { MEAN } \\
\pm\end{array}$} \\
\hline S.E.M. & & $14 \pm 1.1$ & $0.85 \pm 0.25$ & $102 \pm 6$ & $29 \pm 8$ & $298 \pm 22$ & $418 \pm 28$ & $7.5 \pm 0.7$ & $99 \pm 51$ \\
\hline 8 & M & 16 & 5.0 & 92 & $52^{(+)}$ & 321 & 476 & 5.7 & 59 \\
\hline 9 - & $\mathrm{F}$ & 12 & 5.5 & 157 & 46 & 398 & 489 & 10.1 & 286 \\
\hline 10 & M & 10.5 & 5.0 & 104 & 36 & 369 & 504 & 7.9 & 39 \\
\hline 11 & $\mathrm{~F}$ & 13 & 5.0 & 99 & 54 & 344 & 454 & 8.9 & 75 \\
\hline 12 & $\mathrm{~F}$ & 17 & 6.0 & 148 & $90^{(+)}$ & 342 & 445 & 9.0 & 109 \\
\hline 13 & $\mathrm{~F}$ & 12 & 7.0 & 120 & 38 & 474 & 569 & 10.7 & 179 \\
\hline 14 & M & 21 & 8.0 & 114 & 32 & 401 & 511 & 7.7 & 123 \\
\hline \multicolumn{10}{|l|}{$\begin{array}{l}\text { MEAN } \\
\pm\end{array}$} \\
\hline S.E.M. & & $14.5 \pm 1.4$ & $5.89 \pm 0.45^{\mathrm{a}}$ & $119 \pm 9$ & $50 \pm 7$ & $378 \pm 19$ & $493 \pm 16$ & $8.6 \pm 0.6$ & $124 \pm 32$ \\
\hline $\begin{array}{l}\text { norm } \\
\text { norm } \\
(+) \text { split }\end{array}$ & $\begin{array}{l}\text { ralue } \\
\text { ralue } \\
\text { e of }\end{array}$ & $\begin{array}{l}\mathrm{IbAl}_{\mathrm{c}} \text { (child } \\
\text { erum trigly }\end{array}$ & $\begin{array}{l}\text { n) }=2.1-4.8 \\
\text { ride }=40-15\end{array}$ & $0 \mathrm{mg} / \mathrm{dl}$ & & $\begin{array}{l}\text { sho } \\
\text { A rec } \\
\text { cata }\end{array}$ & $\begin{array}{l}\text { tature } \\
\text { ly out of remi } \\
\text { ts }\end{array}$ & sion phase & \\
\hline
\end{tabular}

plasma glucose and serum CPR collected at $0,2,5,10,20,40$, and $60 \mathrm{~min}$. Blood samples for $\mathrm{HbA}_{\mathrm{lc}}$ and serum triglyceride determinations were obtained prior to the oral glucose tolerance test.

Glucose was determined by the glucose oxidase method using the Technicon autoanalyzer. Plasma glucagon [14] was measured by radioimmunoassay. The sensititivity of our glucagon assay is $40 \mathrm{pg} / \mathrm{ml}$ and the normal range is $40-120 \mathrm{pg} / \mathrm{ml} \mathrm{HbA}_{1 \mathrm{c}}$ was determined by a modification of the method of Trivelli $[15,16]$. Mean haemoglobin $\mathrm{A}_{1 \mathrm{c}}$ values on 260 normal children, ages 2-18, with no family history of diabetes mellitus are $3.3 \pm 0.7 \%$ ( 1 standard deviation) with a range of $2.1-4.8 \%$ [17]. Serum triglycerides were measured enzymatically [18].

Serum CPR [1] and serum free C-peptide [10] were measured by radioimmunoassay. All C-peptide samples were measured in duplicate in the same assay. The antisera used for these studies was Faber's M 1230 for which proinsulin has $11 \%$ the reactivity of C-peptide [19]. In two patients with extremely high total basal serum CPR levels (7 and 2, Figure 2) assays for free C-peptide were done to exclude the possibility that the high values were attributable to antibody-bound proinsulin [10].

The sensitivity of the C-peptide assay was $0.06 \mathrm{pmol} / \mathrm{ml}$. The $95 \%$ confidence limits for concentrations below $2.0 \mathrm{pmol} / \mathrm{ml}$ were $\pm 0.1 \mathrm{pmol} / \mathrm{ml}$; in the order of $2.0 \mathrm{pmol} / \mathrm{ml}$, they were $\pm 0.2 \mathrm{pmol} / \mathrm{ml}$, and for concentrations of $4.0 \mathrm{pmol} / \mathrm{ml}$ were $\pm 0.3 \mathrm{pmol} / \mathrm{ml}$. In the few samples with concentrations of total $\mathrm{C}$-peptide as high as $6.0 \mathrm{pmol} / \mathrm{ml}$ the confidence limits were $\pm 0.4 \mathrm{pmol} / \mathrm{ml}$. Since the free C-peptide assay involves a twofold dilution of serum, the sensitivity of this assay is $0.12 \mathrm{pmol} / \mathrm{ml}$. Because values are multiplied by 2 , the coefficient of variation is also doubled. We assume that most CPR in the non-responders is due to antibody-bound proinsulin, but it is difficult to quantitate this. Because of the sample dilution involved in the free insulin assay, levels below $0.2 \mathrm{pmol} / \mathrm{ml}$ cannot be distinguished from zero. This is true because the large coefficient of variation at the low end of the curve shows that samples of $0.12 \mathrm{pmol} / \mathrm{ml}$ (free insulin) produce a $10 \%$ or greater displacement of label only half of the time.

Comparisons of provocative testing for the two groups of diabetics were done using the Student's t-test [20] as well as analysis of variance.

\section{Results}

It can be seen from Table 1 that differences in \% $\mathrm{HbA}_{1 \mathrm{c}}$ and serum triglycerides between the two groups were not significant. There were two patients $(6,9)$, one from each group, with clearly elevated serum triglyceride levels. The mean present ages of both groups were similar although the longer-term patients developed diabetes at an earlier age ( $8.9 \mathrm{vs}$ 13.1 years). However, the data on the younger shortterm patients was not significantly different from the older short-term ones. Mean total daily insulin doses tended to be less for the patients with diabetes of shorter duration: $39 \pm 8 \mathrm{U}$ compared with $50 \pm 7 \mathrm{U}$ $(0.05<\mathrm{p}<0.10)$. 


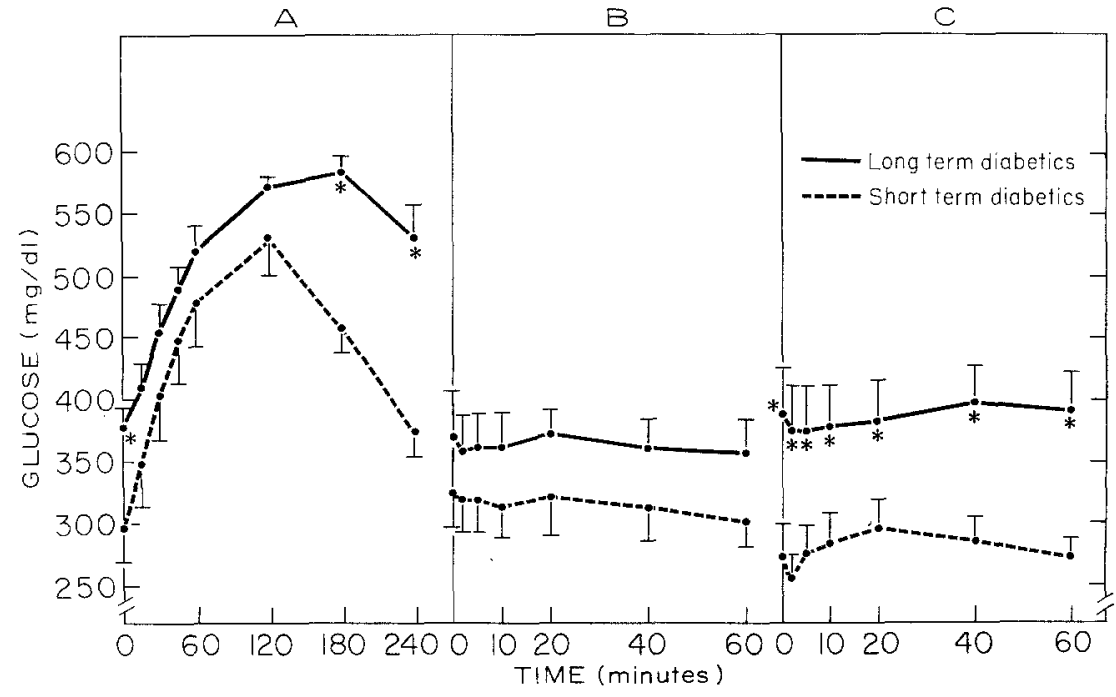

Fig. 1. Mean plasma glucose levels in $\mathbf{A}$ glucose tolerance test, $\mathbf{B}$ tolbutamide tolerance test, and $\mathbf{C}$ glucagon stimulation test in short-term and long-term diabetics. Results are presented as mean \pm SEM. ${ }^{*}=$ significant difference between the two groups $(\mathrm{p}<0.05)$
Mean fasting plasma glucose levels were higher in the long-term diabetics for all the tests. Mean plasma glucose levels during the oral glucose tolerance test (Fig. 1a) were higher for the long-term diabetics at 0 , 180 , and 240 minutes $(p<0.05)$. However, the incremental areas for glucose during the glucose tolerance test were similar-918 vs $960(\mathrm{p}>0.05)$. Mean plasma glucose concentrations during the tolbutamide tolerance test (Fig. 1b) were not significantly different between the two groups. Mean plasma glucose levels during the glucagon stimulation test (Fig. 1c) were significantly higher at every point sampled for the long-term diabetics $(\mathrm{p}<0.05)$. However, plasma glucose did not rise significantly in either group following glucagon stimulation. Basal plasma glucagon values were not significantly different between the short-term diabetics $(161 \pm 11 \mathrm{pg} / \mathrm{ml})$ and the longterm diabetics $(146 \pm 10 \mathrm{pg} / \mathrm{ml})$.

Mean basal serum CPR values on the three different days of testing were significantly greater for the diabetics with less than two years duration $(0.94$ \pm 0.37 vs $0.14 \pm 0.04 ; p<0.05)$. Although all seven long-term diabetics had detectable basal serum CPR values $(\geqslant 0.06 \mathrm{pmol} / \mathrm{ml}$ on at least one occasion) only one, (14), had a value $\geqslant 0.20 \mathrm{pmol} / \mathrm{ml}$ whereas all of the short term diabetics had basal values $\geqslant 0.20 \mathrm{pmol} / \mathrm{ml}(\mathrm{p}<0.05)$.

As shown in Figure 2, mean serum CPR values during the oral GTT were significantly greater at 60 and 120 minutes for the recent onset group $(\mathrm{p}<$ 0.05). For the tolbutamide tolerance test (Fig. 2b), the mean serum CPR values were also greater for those with diabetes for less than 2 years at all points $(p<0.05)$. Mean serum CPR levels during glucagon stimulation (Fig. 2c) were similarly greater for recent onset diabetics although not statistically significant $(0.05>\mathrm{p}<0.10)$. There was a large patient to patient variation in the serum $\mathrm{C}$-peptide response to glucagon in the short term diabetics with 2 patients having much higher responses than the other 5 . For each of the two diabetic groups, none of the mean changes in CPR levels between the basal and stimulated state during the three provocative tests was statistically significant.

Only 1 of 7 of the patients who had diabetes for over five years responded to any of the stimuli, while all seven of the recent onset group responded to at least one provocative test of C-peptide secretion. Within the long-term group the one responder had an $0.15 \mathrm{pmol} / \mathrm{ml}$ increase in serum CPR only after tolbutamide. Within the short-term group, patient no. 1 had significant increments in serum CPR levels with all three stimuli, no. 6 had increases with both glucose and glucagon, two $(5,2)$ responded just to glucose, one (3) responded only to glucagon, one (7) responded to both glucose and tolbutamide, and one (4) responded only to tolbutamide. It is important to note that the mean increases in CPR following the 3 stimuli were variable. Thus, 5 of 7 patients responded to glucose (with a mean CPR increase of $0.26 \mathrm{pmol} /$ $\mathrm{ml}$ ); 4 of 7 responded to tolbutamide (with a mean CPR increase of $0.28 \mathrm{pmol} / \mathrm{ml}$ ), and 3 of 7 responded to glucagon (with a mean CPR increase of $0.62 \mathrm{pmol} /$ $\mathrm{ml}$ ). The overall mean increase in $\mathrm{CPR}$ was $0.36 \mathrm{pmol} / \mathrm{ml}$ for the $12 / 21$ positive responses in the short term group compared with only $1 / 21$ increased responses in the long-term group.

There was no correlation between basal C-peptide levels, or the response of CPR to any of the three stimuli and duration of diabetes, glycaemic control, mean plasma glucose levels or $\mathrm{HbA}_{1 \mathrm{c}}$ concentrations. Of note, however, the two patients ( 5 and 2 ) with the 


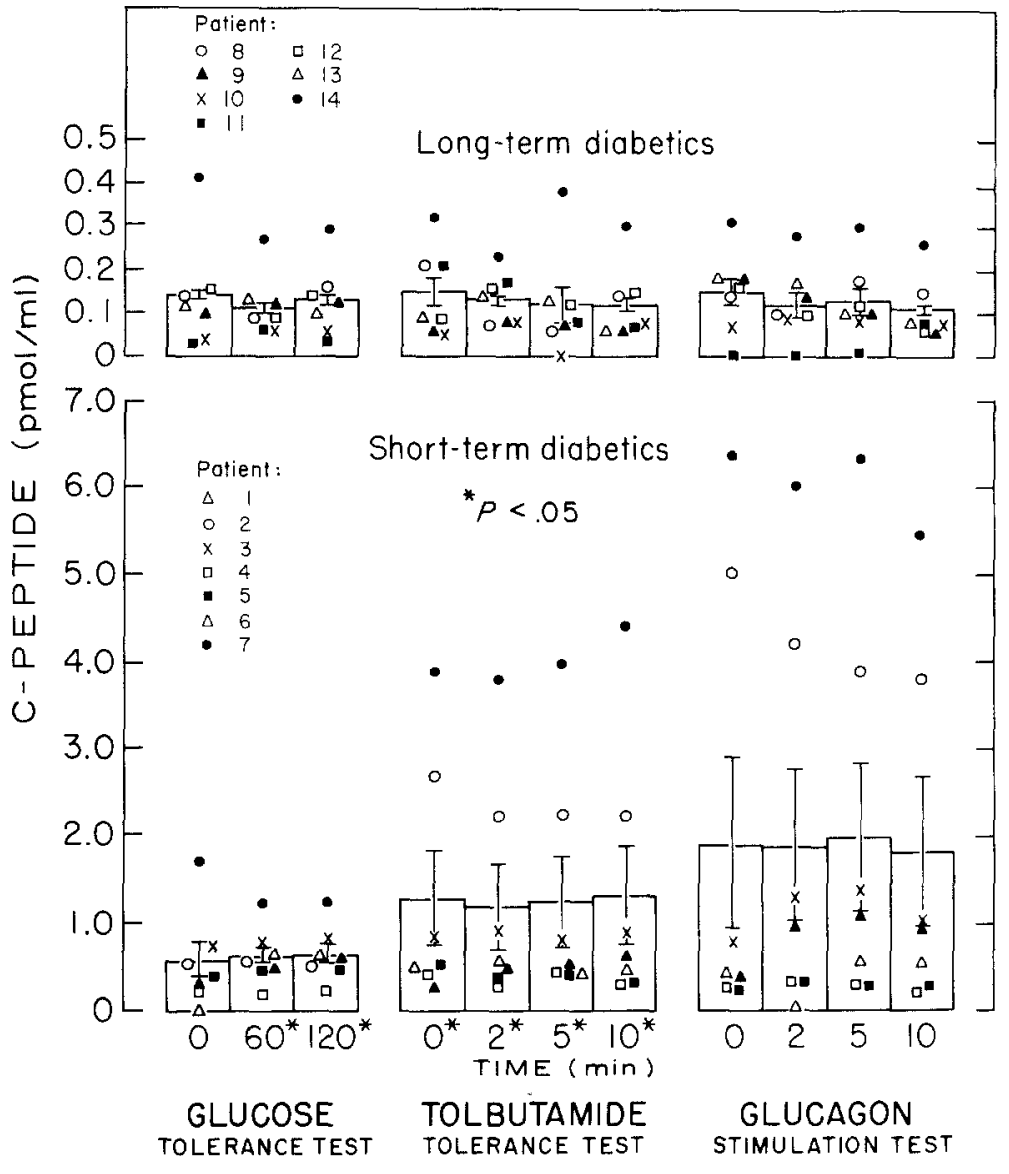

Fig. 2. Serum total C-peptide reactivity $(\mathrm{pmol} / \mathrm{ml})$ in glucose tolerance test, tolbutamide tolerance test, and glucagon stimulation test in short-term and long-term diabetics. Results are presented as individual values for both groups of patients as well as mean \pm SEM. ${ }^{*}=$ significant difference between the two groups $(p<0.05)$ lowest total daily insulin doses had the highest mean basal serum CPR levels. However, neither responded to all three stimuli: no. 5 responded to glucose and glucagon, and no. 2 only to glucose. In the patients, measurements of free $\mathrm{C}$-peptide were made to determine whether the high levels could be ascribed to antibody-bound proinsulin and the results confirm that this was not the case. Calculation of mean basal and stimulated CPR using both the free and total CPR for these 2 patients revealed a $17 \%$ decrease in mean values if the free CPR levels were employed but no change in the response patterns. Thus, no. 5 showed increases in free CPR after tolbutamide from 2.55 to $3.04 \mathrm{pmol} / \mathrm{ml}$ compared with an increase from 3.77 to $4.41 \mathrm{pmol} / \mathrm{ml}$ when total CPR was measured.

\section{Discussion}

The availability of C-peptide measurement by radioimmunoassay since 1970 [21] has enabled studies of endogeneous insulin secretion to be carried out on patients in whom circulating insulin antibodies are present. Block et al. [2] correlated serum C-pep- tide levels after glucose loading with remission and relapse phases of diabetes. Block et al. [1] and Heding [8] established values for normal C-peptide responses showing increments of $\mathrm{C}$-peptide between 1.5 and $1.9 \mathrm{pmol} / \mathrm{ml}$ over basal values one hour after glucose challenge. Furthermore, both Heding [8] and Kuzuya at al. [11] showed that diabetics did have some, although decreased, C-peptide responses to a glucose challenge. Their groups of patients, however, were not clearly homogenous with regard to the type of diabetes or age of patients. In our group, $5 / 7$ shortterm diabetics responded to oral glucose with a mean $0.26 \mathrm{pmol} / \mathrm{ml}$ increase in C-peptide reactivity. In a study of 35 insulin-dependent diabetics Grajwer et al. [22] showed that a greater percentage of patients with diabetes for less than five years had detectable basal CPR levels as compared to those with diabetes for over five years. Since only one patient responded to a glucose challenge, they concluded that maximum stimulation was present basally and that there was little C-peptide reserve in either group. They found no correlation between diabetic control and serum CPR levels nor between serum CPR levels and age of onset, total insulin dose, fasting glucose or change in glucose after glucose challenge. The degree of diabe- 
tic control was not assessed with haemoglobin $A_{1 c}$ determinations. Criteria for $\mathrm{C}$-peptide response to glucose challenge, however, are not given. Although the patient population was heterogeneous, Yue et al. [23] using a group of 35 diabetics showed that the magnitude of the serum C-peptide response to glucose correlated with the degree of stability of diabetic control. Our data using $\mathrm{HbA}_{1 \mathrm{c}}$ as an index of diabetic control do not support this observation.

Other investigators have examined CPR responses to various stimuli in diabetic subjects. Beischer et al. [12] found little correlation between fasting and stimulated CPR levels in response to the combined administration of glucose and a sulphonylurea. Glucagon has also been used as a provocative test for beta cell reserve. Faber and Binder [24] have shown that normals display a peak C-peptide response 4-15 minutes (mean 8.7 minutes) after glucagon administration intravenously and that mean basal values of $0.36 \mathrm{pmol} / \mathrm{ml}$ stimulated to peak levels of $1.28 \mathrm{pmol} / \mathrm{ml}$. Unger et al. [25] and Faber and Binder $[24,26]$ showed that increases in CPR levels occur after intravenous glucagon in diabetics. Finally, Ludvigsson and Heding reported that only 3 of 10 insulin-dependent diabetics whose mean duration of disease was 6.3 years had any C-peptide response to intravenous glucagon secretion [13]. In our group, 3/7 short-term but no longer term diabetics responded to glucagon with a mean increase of $0.62 \mathrm{pmol} / \mathrm{ml} \mathrm{compared} \mathrm{with} 0.92 \mathrm{pmol} / \mathrm{ml}$ in the normals described above. Thus, our data support the suggestion that glucagon [24] may be the best test for beta cell reserve in diabetics.

Heding reported absent fasting CPR levels in 21 of 24 insulin treated diabetics (ages 17-67) with a duration of disease ranging from 1-29 years [27]. In our study, however, basal CPR levels were detectable at least once in all patients studied.

There are several difficulties in the interpretation of the above studies and extrapolating from these data to any one group of diabetics, particularly insulin-dependent patients. Many of the investigators studied heterogeneous diabetic populations with respect to type of disease, insulin-dependent vs insulin-independent, duration, severity and history of complications. Unfortunately, protocols for provocative testing were not standardardized from study to study. Furthermore, criteria for response of C-peptide to the various stimuli were not uniform.

One may not be able to compare serum CPR responsiveness after any stimulus in diabetics to nondiabetic controls. In our group of seven recent onset diabetics, responses were diminished. Normal young adult responses to either 50 or $100 \mathrm{~g}$ oral glucose vary between 1.5 and $1.9 \mathrm{pmol} \mathrm{C}$-peptide/ml above baseline $[2,8]$. In our patients, we observed a wide spectrum of responses from 0.11 to $0.65 \mathrm{pmol} / \mathrm{ml}$ increments in serum CPR values after stimulation. Increments in total C-peptide are almost certainly due to C-peptide itself as newly secreted proinsulin is miniscule in amount [28] accounting for $<5 \%$ of C-peptide on a molar basis.

The results of this study show that an appreciable C-peptide response was obtained in at least one stimulatory test in all seven recent onset diabetics. Neither the number of responses in the same patient nor the magnitude of the response correlated with the basal serum CPR value. Only one of the patients in the long-term group had significant stimulation with any of the provocative tests. This study differs from previous investigations in that it assessed three stimulatory tests in the same patients in an attempt to determine if, in fact, different stimuli might elicit selective responses in beta cell function. It is clear that, as others had suggested, some insulin-dependent diabetics do respond to various stimuli of insulin secretion. This response may be blunted, as had been previously demonstrated $[8,11,24]$. We infer from these data that mechanisms of insulin release differ depending upon the provocative stimulus used. The clinical significance of the variations in response is not clear.

It is noteworthy that the two patients with the highest basal CPR values, although they did not have the greatest increments after stimulation, were both in partial remission, as defined by rapidly decreasing insulin requirements after diagnosis.

In conclusion, this study demonstrates that in a small group of insulin-dependent diabetics, basal serum levels of CPR do not totally reflect endogenous beta cell reserve as measured by additional provocative testing. Our data support previous studies which suggested that patients may respond differently to various stimuli of insulin secretion. In patients with sustained hyperglycaemia, very small amount of proinsulin and C-peptide appear to be secreted by the remaining B-cells. Those with the most limited beta cell reserve and significant basal hyperglycaemia cannot further augment insulin secretion. Their ongoing C-peptide secretion is thus too low to be measured, but proinsulin is retained in the circulation by insulin binding antibodies and reaches levels measurable as total C-peptide. Finally, stimulation tests are only useful in assessing endogenous beta cell reserve in patients with diabetes of less than 5 years duration. In diabetics of longer duration there is little insulin reserve above basal levels.

Acknowledgements. Supported in part by grants from the NIH (AM-18522, AM-19206), a USPHS Diabetes Research and Training Center (AM-20595) at the University of Chicago, the New 
York Diabetes Association, and NIH Career Development Awards to Dr. Horwitz (AM-00181) and to Dr. Rayfield (AM-00089).

\section{References}

1. Block MB, Mako ME, Steiner DF, Rubenstein AH (1972) Circulating C-peptide immunoreactivity: studies in normals and diabetic patients. Diabetes 21: 1013-1026

2. Block MB, Rosenfield RL, Mako ME, Steiner DF, Rubenstein AH (1973) Sequential changes in beta cell function in insulin-treated diabetic patients assessed by C-peptide immunoreacitivity. $\mathrm{N} \cdot$ Engl J M 288: 1144-1148

3. Cahill GF Jr (1973) C-peptide: a new method of assessing pancreatic beta cell function (editorial). $N$ Engl $J$ Med 288: $1181-1182$

4. Heding LG, Rasmussen SM (1975) Human C-peptide in normal and diabetic subjects. Diabetologia 11: 201-206

5. Horwitz DL, Kuzuya H, Rubenstein AH (1976) Circulating serum C-peptide: a brief review of diagnostic implications. $\mathrm{N}$ Engl J Med 295: 207-209

6. Horwitz DL, Rubenstein AH, Katz AI (1977) Quantitation of human pancreatic beta-cell function by immunoassay of Cpeptide in urine. Diabetes 26: 30-35

7. Kitabchi AE (1977) Proinsulin and C-peptide: a review. Metabolism 26: 547-587

8. Heding LG (1975) Radioimmunological determination of human C-peptide in serum. Diabetologia 11: 541-548

9. Beischer W, Keller L, Maas M, Schiefer E, Pfeiffer EF (1976) Human C-peptide. Part I: radioimmunoassay. Klin Wochenschr 54: 709-715

10. Kuzuya H, Blix PM, Horwitz DL, Steiner DF, Rubenstein AH (1977) Determination of free and total insulin and C-peptide in insulin-treated diabetics. Diabetes 26: 22-29

11. Kuzuya T, Matsuda A, Saito T, Yoshida S (1976) Human Cpeptide immunoreacitivity (CPR) in blood and urine-evaluation of radioimmunoassay method and its clinical applications. Diabetologia 12: 511-518

12. Beischer W, Heinze E, Keller L, Raptis S, Kerner W, Pfeiffer EF (1976) Human C-peptide. Part III: clinical studies. Klin Wochenschr 54: 717-725

13. Ludvigsson J, Heding LG (1977) C-peptide in diabetic children after stimulation with glucagon compared with fasting C-peptide levels in non-diabetic children. Acta Endocrinol (Kbh) 85: 364-371

14. Unger RH, Aguilar-Parada E, Müller WA, Eisenstraut AM (1970) Studies of pancreatic alpha-cell function in normal and diabetic subjects. J Clin Invest 49: 837-848

15. Trivelli LS, Ranney HM, Lai H-T (1971) Hemoglobin compo- nents in patients with diabetes mellitus. N Engl J Med 284: 353-357

16. Koenig RJ, Peterson CM, Jones RL, Saudek C, Lehrman M, Cerami A (1976) Correlation of glucose regulation and hemoglobin $A_{1 c}$ in diabetes mellitus. N Engl J Med 295: 417-420

17. Ginsberg-Fellner F, Dobersen M, Witt M, Notkins A, Rubinstein P, Rayfield EJ (1979) HLA antigens, islet cell antibodies and carbohydrate metabolism in siblings of children with insulin-dependent diabetes mellitus (Abstract). Diabetes [Suppl] 28: 396

18. Bucolo G, David H (1973) Quantitative determination of serum triglycerides by use of enzymes. Clin Chem 19: 476-482

19. Faber OK, Binder C, Markassen J, Heding LG, Naithani VK, Kuzuya H, Blix P, Horwitz DL, Rubenstein AH (1978) Characterization of seven C-peptide antisera. Diabetes [Suppl] 27: $170-177$

20. Snedecor GW, Cochran WG (1967) Statistical methods, 6th ed, 91. The Iowa State Univ Press, Ames, Iowa

21. Melani F, Rubenstein AH, Steiner DF (1970) Human serum proinsulin. J Clin Invest 49: 497-507

22. Grajwer LA, Pildes RS, Horwitz DL, Rubenstein AH (1977) Control of juvenile diabetes mellitus and its relationship to endogenous insulin secretion as measured by C-peptide immunoreactivity. J Pediatr 90: 42-48

23. Yue DK, Baxter RC, Turtle JR (1978) C-peptide secretion and insulin antibodies as determinants of stability in diabetes mellitus. Metabolism 27: 35-44

24. Faber OK, Binder C (1977) C-peptide response to glucagon: a test for the residual B-cell function in diabetes mellitus. Diabetes 26: $605-610$

25. Unger RH, Aydin I, Nakabayashi $H$, Srikant CB, Raskin $P$ (1976) The effects of glucagon administration to non-diabetics and diabetics. Metabolism [Suppl 1] 25: 1523-1526

26. Binder C, Faber OK (1978) Residual beta-cell function and its metabolic consequences. Diabetes [Suppl] 27: 226-229

27. Heding LG (1978) Insulin, C-peptide, and Proinsulin in nondiabetics and insulin-treated diabetics. Diabetes [Suppl 1] 27: 178-183

28. Horwitz DL. Starr JI, Mako ME, Blackard WG, Rubenstein AH (1975) Proinsulin, insulin, and C-peptide concentrations in human portal and peripheral blood. J Clin Invest 55: 1278-1283

Received: May 25, 1979,

and in revised form: February 5, 1980

Dr. Elliot J. Rayfield

Mount Sinai School of Medicine

Fifth Avenue and 100th Street

New York, N Y 10029, USA 